\title{
A STUDY OF ARGOPURO SPECIALTY COFFEE DISTRIBUTION CHANNEL
}

\author{
Muhlisin Ahmad*, Rifin Amzul, Setiadi Djohar \\ Bogor Agricultural University, Bogor, Indonesia \\ *E-mail: muhlisinahmad305@gmail.com
}

\begin{abstract}
Specialty coffee is one form of coffee products that has developed into a niche market in the last five years in Indonesia. The development of the specialty coffee market starts from the many coffee shops that have sprung up in urban areas. This study focuses on the efficiency analysis of the Argopuro specialty coffee distribution channel. Argopuro as a single origin and new producer of specialty coffee requires a study of distribution channels that have been running in the past three years in order to develop efficient channels. Research location is located in Tlogosari Village, Sumbermalang Sub-district, Situbondo Regency. The sampling method is taken by non-probabling sampling by focusing on actors in each distribution channel. The sample consisted of 20 assisted farmers, 1 processor and 7 home roasters. The results of the study showed that the farmer share obtained by farmers in the Argopuro specialty coffee business is $36 \%$. While the marketing strategy of each distribution chain actor includes; farmers $(48 \%)$, processors $(53 \%)$, and roastery $(48 \%)$. Percentage of profit and cost ratio is obtained evenly between market institutions. Prossesor has a profit ratio of $83 \%$ and costs $73 \%$. While roastery has a profit ratio of $73 \%$ and a cost ratio of $80 \%$. Based on these indicators, the Argopuro specialty coffee distribution channel is efficient in terms of margin share, profit share and cost share. However, the purchase price at the farmer level needs to be considered so that the portion of the farmer share can be increased.
\end{abstract}

\section{KEY WORDS}

Specialty coffee, efficiency, distribution channel, farmer share.

The number of coffee shops that have emerged has made domestic demand of specialty coffee continue to grow in the last five years (AEKI 2016). Coffee consumption trends in urban communities are beginning to shift in the direction of quality and unique coffee brewing methods such as manual brewing. Consumers begin to pay attention to the flavors and stories of the coffee they drink, for example the origin of planting, varieties, and cultivating farmers. The development of the specialty coffee market is inseparable from the growth of association institutions that have grown to introduce specialty coffee such as SCAI (Specialty Coffee Association of Indonesia) and AEKI (Association of Indonesian Coffee Exporters). Specialty coffee with all its uniqueness grows into a niche market with specific segments. The developing price is no longer determined by supply and demand, but is determined by the quality and uniqueness of the produced flavor. The term of specialty coffee was first introduced by Erna Knutsen in 1980. Specialty coffee is the best quality coffee, processed with the right post-harvest, has a geographical indication of the planting location, seed moisture content is no more than $12 \%$ and cultivated with the concept of sustainability (Donnet 2007).

The specialty coffee market in Indonesia has a pretty good trend. The development of the domestic specialty market has continue to grow since 2008 marked by the rise of coffee shops in urban areas and began to emerge with many specialty coffee producers from various highland regions in Indonesia. Consumer of specialty coffee grows by $6 \%-8 \%$ per capita per year (AEKI 2014). However, the premium prices available in specialty coffee products have not added much value, especially in the upstream sector. More value is enjoyed by downstream actors such as collectors and retailers. Marketing channels that are too long make the value added on the farm level still small. There are many farmers who pick carelessly, due to limited knowledge in conducting the harvest process with a specialty coffee standard, and another factor is the low value added received by farmers who process 
specialty coffee. Therefore, it is necessary to improve the marketing channel so the farmer share can be better. This study was conducted to find out the actors who play a role in the Argopuro specialty coffee distribution channel and analyze the efficiency of distribution channels by focusing on farmer share analysis, revenue margin, and percentage ratio of profit to cost.

\section{METHODS OF RESEARCH}

The conceptual framework of this research was carried out using qualitative and quantitative approaches. Finding the role of distribution chain actors was done by descriptive analysis using questionnaire tools to obtain data sources. Furthermore, the marketing channel efficiency indicators are analyzed through quantitative methods. The quantitative method used focuses on farmer share analysis, marketing margins, and benefit shares and costs of each actor in the distribution chain.

The research took place at Tlogosari Village, Sumbemalang Sub-district, Situbondo Regency, East Java. The focus of this research is Argopuro specialty coffee distribution chain actors consisting of 20 assisted farmers, one leader of processing institutions (Pokmas Walida), and 7 people who are home roasters who have used Argopuro specialty coffee in the past three years.

The analysis of the loyal role of marketing actors used qualitative methods with descriptive analysis by collecting data through questionnaires and direct interviews with informants. The data taken is in the form of goods channel flow and information that occurs in the Argopuro specialty coffee business process. In addition, the roles of each distribution chain actor will be described descriptively.

Farmer share analysis is done by quantitative methods. Kusuma et al. (2013) calculate farmer shares by comparing prices received by farmers with prices received by consumers by the formula:

$$
F s=\left(\frac{P f}{P r}\right) \times 100 \%
$$

Where: $F s=$ part received by farmers; $\mathrm{Pf}=$ selling price at the farmer level $(\mathrm{Rp} / \mathrm{Kg})$; $\operatorname{Pr}=$ selling price at the consumer level $(\mathrm{Rp} / \mathrm{Kg})$.

A distribution channel is declared efficient if it has a value of $\geq 40 \%$, and declared inefficient if it has a value of $\leq 40 \%$.

In addition to farmer share value, the efficiency of the marketing channel is also seen from the size of the marketing margin. Marketing margin is the difference in prices received by farmers with prices paid by consumers. In this study the data used are farmer-level prices and marketing institutional-level prices ranging from processors, distributors, roasters to baristas. Referring to Mayrowani and Darwis (2009) marketing margin calculations using the formula:

$$
M m=P e-P f
$$

Where: $\mathrm{Mm}=$ marketing margin at the farm level; $\mathrm{Pe}=$ prices at the marketing institutional level; $\mathrm{Pf}=$ prices at the farm level.

Meanwhile the margin in each marketing institution is calculated by comparing the purchase price and selling price with the formula:

$$
M m=P s-P b
$$

Where: $\mathrm{Mm}=$ marketing margins at each level of marketing institutions; $\mathrm{Ps}=$ selling prices at each level of the marketing institutes; $\mathrm{Pb}=$ purchase price at each level of the marketing institutes. 
Because in the marketing margin there are two components, namely the cost component and the profit component of the marketing institution, so:

$$
\begin{gathered}
M m=c+\Pi \\
P e-P f=c+\Pi \\
P f=P e-c-\Pi
\end{gathered}
$$

Where: $c=$ marketing costs; $\Pi=$ marketing institute profits.

In addition to farmer share and marketing margin, an analysis of the efficiency of the distribution channel can also be done by looking at the value of the profit and costs of the marketer institution. Kusuma et al. (2013) stated that to look at marketing efficiency quantitatively it can be used to analyze share costs and share of marketing profits can be calculated using the formula:

$$
\begin{aligned}
& S k i=\left(\frac{K i}{\operatorname{Pr}-P f}\right) \times 100 \% \\
& S b i=\left(\frac{B i}{\operatorname{Pr}-P f}\right) \times 100 \%
\end{aligned}
$$

Where: $\mathrm{Ki}=\mathrm{i}$-profit of the marketing institute; $\mathrm{Bi}=\mathrm{i}$-marketing costs; $\mathrm{Ski}=\mathrm{i}$-profit shares of the marketing institute; $\mathrm{Sbi}=\mathrm{i}$-shares of marketing costs.

From those formula, the level of efficiency of the marketing channel can be determined by referring to the following criteria:

- If the ratio of profit and cost shares in each marketer institution is evenly distributed, then the channel is declared efficient;

- If the ratio of profit and cost shares in each marketer institution is uneven, then the channel is declared inefficient.

\section{RESULTS AND DISCUSSION}

Argopuro Specialty Coffee Distribution Channel. Specialty coffee as a niche market product requires strong integration among its distribution chain actors. The quality of products that are interconnected in each channel makes many specialty processors do direct selling with $\mathrm{B} 2 \mathrm{~B}$ consumers. In addition to maintaining the quality of sold products, short distribution chains make a channel more efficient. Nevertheless, an evaluation of the distribution channel and processors' performance is needed as a means of determining the quality of green beans at the level of the farm. In the specialty coffee industry the role of farmers and processors is very important because being the first who determines the green beans can be said a special standard. After that the roaster plays a role in making the flavor of the green beans to come out maximally. The last task was Barista as a brewer that served as a channel to deliver the farmer's work, processors and roastery to end consumers in the form of liquid coffee.

Roastery and Barista as downstream players need constant quality of green beans and the existence of continuous goods. These two things are the main needs that must be met by farmers and processors who are on the farm level. The situation of farmers who have not known about specialty coffee has made the processor role as a person who can maintain the quality of coffee, so that the downstream players have trust in using the produced green beans. Processor can play a role as a farmer and some will only act as coaches and take the cherry from farmers. In this research Pokmas Walida as a single processor has a role as a coach and takes cherry from farmers who are in the coaching status. As a single player in Argopuro, Pokmas Walida has a strong bargaining power as a price determinant of the cherry produced by assisted farmers. The results of the analysis of members of the Argopuro specialty coffee distribution channel are as follows (Figure 1). 
Channel 1:

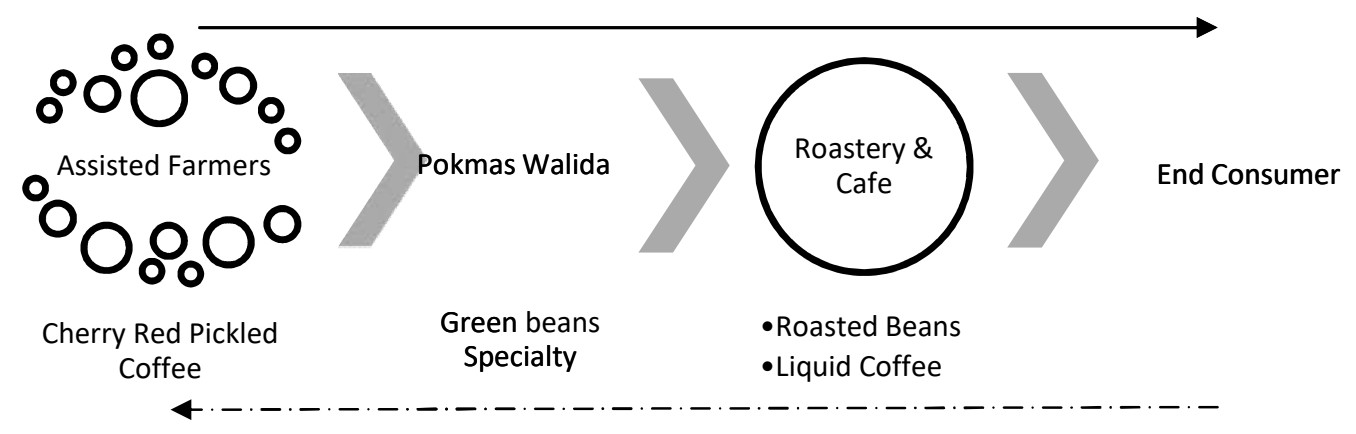

Channel 2:

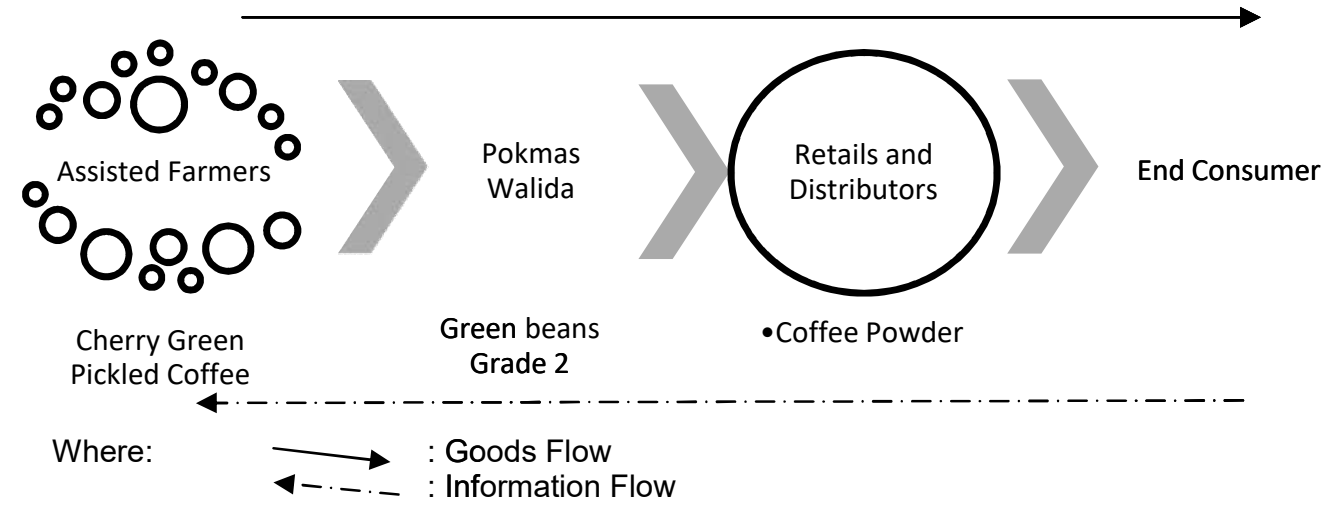

Figure 1 - Goods distribution flow of Argopuro specialty coffee (Primary Data 2017)

Members of the primary distribution channel Argopuro Specialty Coffee consists of 3 components, namely: Farmers as suppliers, Pokmas Walida as Processor, and Roastery and coffee shops as consumers. In short, this distribution channel results in price fixing between members is more transparent. From those three members, coffee processing starts from the processor and roast level, while the assisted farmers become suppliers of raw materials in the form of red cherry picking.

Table 1 - Input and output of distribution channel members of Argopuro specialty coffee

\begin{tabular}{llll}
\hline & Farmer & Processor & Roaster \\
\hline Input & Nursery, cultivation, & $\begin{array}{l}\text { Post-harvest } \\
\text { processing, }\end{array}$ & $\begin{array}{l}\text { Roasting green beans at certain levels, } \\
\text { Cupping }\end{array}$ \\
& harvesting & Sorting & Roasted beans \\
\multirow{2}{*}{ Output } & $\begin{array}{l}\text { Red Pickled Cherry } \\
\text { Green Pickled Cherry }\end{array}$ & $\begin{array}{l}\text { Coffee Powder } \\
\text { Liquid coffee }\end{array}$ & $\begin{array}{l}\text { Rouns } \\
\text { Lick }\end{array}$ \\
\hline
\end{tabular}

Coffee farmers play the role of supplier for Pokmas Walida. At that time there are 20 farmers assisted by Pokmas Walida. These farmers are given seed and fertilizer facilities when planting. While further maintenance is assisted farmers' charge. The form of cooperation that is carried out is cooperation in the purchase of cherry coffee by Pokmas Walida at a special price higher that unassisted farmer. However, the quality of cherry must be in accordance to the standard of Pokmas Walida. Deposited cherry coffee must be red pickled with a defact tolerance of $20 \%$. Currently the average age of coffee plantations of assisted farmers is 5 years. Harvesting systems are carried out periodically between April and September each year. Costs that come out during the harvest season are borne by assisted farmers.

Total land area of farmers assisted by Pokmas Walida is 16 ha. The status of assisted farmers' land is owned by Perhutani with a $30 \%$ profit sharing for Perhutani. But practically, Perhutani usually directly asks for cash from Pokmas Walida. So that the assisted farmers no longer need to divide the harvested coffee and simply deposit it directly to Pokmas Walida. 
On average, each farmer can produce 2 to 3 tons of red pickled cherry every time they harvest. The quality of red pickled of assisted farmers is the initial determinant of production amount and the quality of the harvest in that year.

Table 2 - Characteristics of Pokmas Walida assisted farmers

\begin{tabular}{l|ll}
\hline & \multicolumn{2}{l}{ Characteristics of assisted farmers } \\
\hline Variable & Indicator & Total \\
& $<0.5$ & 4 \\
Land area (ha) & $0.5-1$ & 11 \\
& $>1$ ha & 5 \\
Income per harvest (rp) & $<5$ million & 12 \\
& $5-10$ million & 6 \\
Education & $>10$ million & 3 \\
& Elementary school & 9 \\
\hline
\end{tabular}

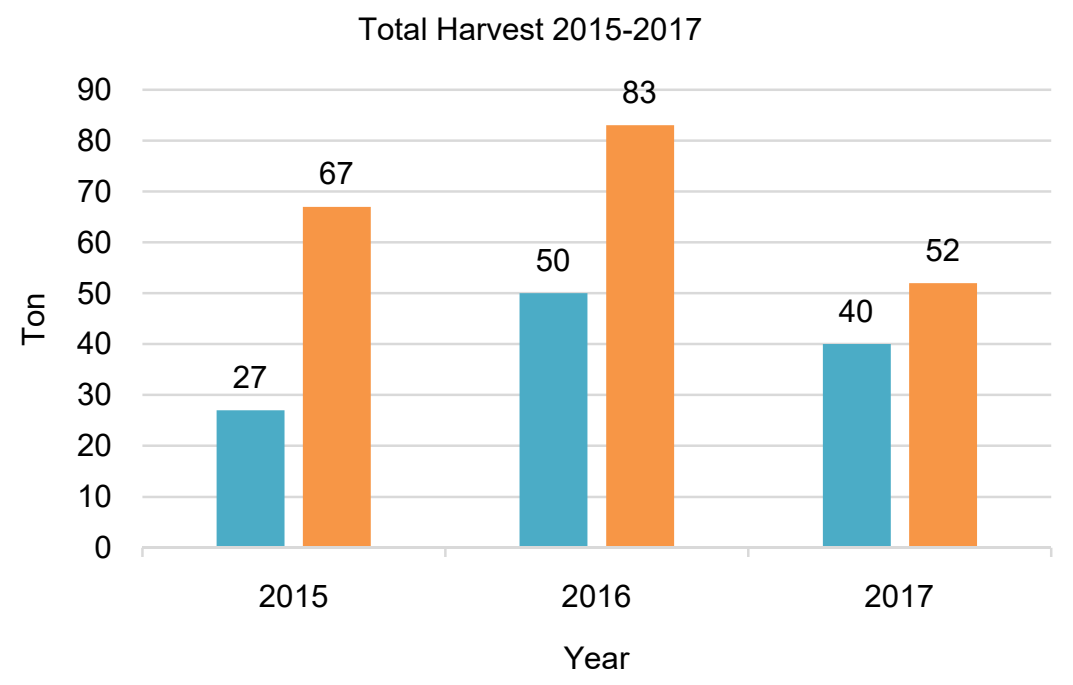

Figure 2 - Argopuro productivity of assisted farmers in three years

From the graph it can be seen that the quality of red pickled of assisted farmers is increasing from year to year. This is in line with the price of red pickled cherry which is increasing from Rp. 6000/kg in 2015, Rp. 6500/kg in 2016 and lastly to Rp.8000/kg in 2017. In 2015 the number of red pickled cherry from assisted farmers was only around $20 \%$ of the total harvest, in 2016 it increased around $60 \%$ of the total harvest, then in 2017 increased to $80 \%$ of the total harvest. Another factor in improving the quality of farmers' red pickled is the request from the processors that standardizes the quality of red pickled at least $80 \%$ of the deposited cherry. In terms of price, red pickled cherry is considered more profitable because the price is more expensive and the weight of the contents is heavier than carelessly picked. Even so, the productivity of coffee by assisted farmers decreased in 2017 due to unfavorable weather factors. High rainfall results in many coffee flowers falling out and failing to become fruit.

Pokmas Walida in the distribution chain acts of Argopuro specialty coffee as the processing institution and main market institution for green beans specialty grade. Red cherry coffee supplied from assisted farmers is processed naturally or better known as dry process. This process was chosen because in Tlogosari Village there was water shortage to process wet fermented coffee.

Cherry coffee supplied by assisted farmers first step is sorting the defact (green seeds and dirt), after that the cherry coffee that passed the sorting is dried for 30-40 days to get $14 \%$ moisture content. This drying step must be carried out with certain standards including: 
during drying the coffee cherry should not be molded (overferment), drying should be done at least 1 meter above the surface of the ground or use anjang and para-para so that there is no earty aroma (smell of soil) in coffee beans. The vulnerable period of this drying stage is 15 days after picking. During this time, coffee beans must be completely free of mold. After the cherry coffee water content reaches $14 \%$, the next step is the Dry-hull process or the process of stripping the coffee horn skin. In this process, coffee beans will be peeled and the output of this process is green beans. The next step is sorting green beans. For sorting Pokmas Walida hired the freelancers with a wage of Rp. $2500 / \mathrm{kg}$. The process of sorting green beans will produce 4 kinds of coffee, namely specialty grade, lanag or peaberry coffee, grade 2 coffee (broken huling) and defact coffee. From the four types of green beans, the specialty grade is on average $70 \%$ of the total weight of green beans before being sorted. The average weight loss and shrinkage of specialty coffee processing are estimated at $83 \%$, which means to produce $1 \mathrm{~kg}$ of green beans specialty grade, $5 \mathrm{~kg}$ of red pickled cerry is needed. This is what causes the price of the green beans specialty grade to be far above the usual grade coffee. Green beans which has been sorted then packaged in PP plastic coated with sacks. The last step is storage in the warehouse.

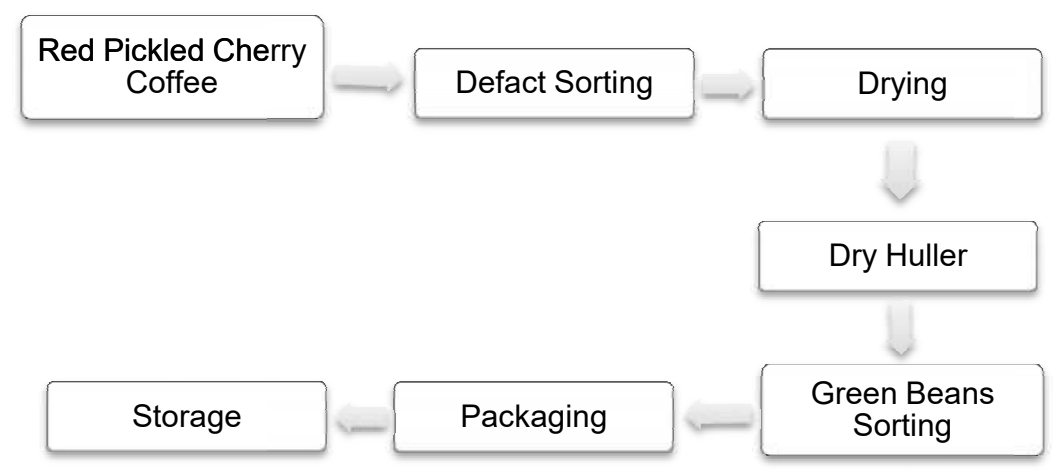

Figure 3 - Flow of natural process of cherry coffee to green beans

The storage of green beans should not touch directly to the warehouse floor, so palettes are needed as green beans sacks. With proper storage, green beans can survive in optimum conditions for 1 year. Humidity and room temperature need to be concerned so that the moisture content of coffee beans does not rise. To minimize the decline in the quality of the green beans, the Pokmas Walida chooses to store coffee in the form of dried beans. This technique is considered safer because the coffee beans are still intact in the skin of the fruit so that the possibility of being attacked by pests and a decrease in water content becomes reduced. When there is order, the dry hull stage and advanced sorting will be done.

For one production batch, it takes an average of 40 days to process the product until it's ready for sale. The drying cotton that Pokmas Walida currently has is 10 ton wet cherry. With this capacity, Pokmas Walida employed 10 people as wet cherry sorting workers, 15 people as drying staff and 20 people as freelancer in green beans sorting.

The price set by Pokmas Walida to the retail market has increased from 2015-2017. In 2015 the price of $1 \mathrm{~kg}$ green beans Argopuro was Rp. 90,000/kg then rose to Rp. 95,000/kg and finally in 2017 rose to Rp. $100,000 / \mathrm{kg}$. This increasing price is because of improvement quality of beans. The increase in green beans in 2017 is very significant because the amount of harvest produced decreases so that the cost needed is slightly increased. Besides that, the Pokmas Walida made improvements in the sorting process by pressing the percentage of the defect estimated at $5 \%$.

Roastery and coffee shops are the main consumers of Argopuro coffee beans, which are processed by the Pokmas Walida. Currently there are at least 70 coffee shops that have become Pokma Walida consumers. From 70 coffee shops, only 7 home roastery use the most of Pokmas Walida products. The rest is a cafa shop that buys roasted beans from roastery. 
At the roastery level, coffee beans purchased from Pokmas Walida will be roasted at a certain level so that the desired flavor can come out perfectly. On average, roastery buys Argopuro green beans, which is estimated at $60-300 \mathrm{~kg}$ per month with an online purchasing system through Instagram and Whatsapp. The distribution system is carried out by transfer to the Pokmas Walida bank account. Transactions with prices set by the Pokmas Walida are green beans prices excluding shipping costs, so shipping costs are borne by the roastery. The shipping service used is PT. Pos Indonesia and Dakota. In addition, shipping services with ESL are also often carried out. Of the three delivery services Dakota is the cheapest expedition for transportation on Java Island. Shipping costs for one shipping batch are an average of Rp. 5000/kg. However, even though the shipping cost is cheap, usually it will be received up to 7 days. But this is not a problem considering the product that shipped is a raw material that put up with rottenness. Costs incurred by roastery in one production process (1 $\mathrm{kg}$ roasted beans) an average of Rp. 143,000. The selling price ranges between Rp. 260,000 to 285,000 per kg roasted beans. Most roastery will sell their products to coffee shops, hotels, and coffee lover.

In addition to the roasting process, the coffee roastery will be tested for flavor, known as the cupping process. In this stage, roasted beans will be calibrated starting from the flavor, acidity and natural sweetness of the coffee. The three indicators will later be elaborated and become a reference for recommendations and education for coffee consumers.

Members of the distribution chain for channel 2 which is coffee from assisted farmers with stringed quality picking ( $80 \%$ Green) consisting of assisted farmers as suppliers of raw materials in the form of green picking, Pokmas Walida as processing agencies, Retail and Distributors as marketers and end consumers.

In this channel the raw material comes from assisted farmers who do knit picking. Raw material for knitting must be done by sorting cherry so that it can be included in the specialty grade. The average green coffee found in raw materials deposited by assisted farmers is estimated at $20 \%$ in 2017 . This figure is far better than the previous year which reached $50 \%$ to $80 \%$. Green Cherry which is not included in the specialty grade is processed by Pokmas Walida naturally. The post-harvest process carried out by Pokmas Walida for green cherry coffee is not much different from the red pickled cherry coffee. The difference is in the green pickled coffee Walida Pokmas conduct a further process by roasting green beans traditionally. The output of processing carried out by Pokmas Walida is packaged coffee powder which is marketed to local retailers and distributors. The sale of coffee powder is not too broad and is only limited in Sumbermalang sub-district. This is because the availability of green coffee cannot be standarized considering the main purpose of coffee production is in the specialty grade which is made from raw red cherry coffee.

Some assisted farmers who do knit picking themselves sort the beans before depositing them to the Pokmas Walida. The farming costs incurred by farmers for picking knits are Rp. 2,500/kg. The green pickled coffee yield is slightly lower than red pickled coffee. For green coffee the yield is $40 \%$. Knit picking has lower farming costs than selective picking. But the price set by Pokmas Walida is much lower. The price of green pickled coffee is Rp. $4,000 / \mathrm{kg}$. Most assisted farmer made reasonable excuse that they don't have enough time and energy to do red picking.

The raw material for knit picking deposited by the farmers then processed by Pokmas Walida to become green beans. The process carried out is the same as the processing of the specialty grade coffee which is the dry process or the natural process. Knit pickled coffee dry faster than red cherry coffee. If it usually takes 40 days for post-harvest processing, then knit picking coffee is only 25 days on average. In knit picking coffee additional processing is also carried out, namely the roasting process. The output of this process is packaged coffee powder. This coffee then distributed to retail stores around Sumbermalang Sub-district. The coffee is packaged in $1 \mathrm{~kg}$ weight. The price for $1 \mathrm{~kg}$ of coffee powder is Rp. 75,000.

Coffee powder which is processed by Pokmas Walida is distributed to retail stores. The retail store will repackaging with $100 \mathrm{gr}$ packaging. The selling price is Rp. 10,000/package. 
The sales system for Pokmas Walida with retail stores is carried out with a deposit system. Payment is made every time the store take repeat order.

Analysis of Farmer share, Marketing Margin and Efficiency. Farmer share is a comparison between the price received by the assisted farmer and the selling price obtained by the market institutions (prossesor). Farmer shares are expressed as percentages and have a negative relationship with marketing margins received by marketers. A distribution channel is said to be effective if the farmer share is higher than the marketing margin. The results of the calculation of the farmer share in the last 3 years are as follows:

Table 3 - Farmer share channel 2

\begin{tabular}{llll}
\hline Year & Prices at the farmer level ${ }^{*}$ Wet spindle & Price at the processor level ${ }^{*}$ Coffee powder & farmer share \\
\hline 2015 & 16000 & 75000 & $21 \%$ \\
2016 & 16000 & 75000 & $21 \%$ \\
2017 & 16000 & 75000 & $21 \%$ \\
Average & 16000 & 75000 & $21 \%$ \\
\hline
\end{tabular}

Table 4 - Profit percentage of Argopuro coffee distribution channel

\begin{tabular}{lllll}
\hline Distribution Members & \multicolumn{2}{l}{ Cost (Rp./Kg Green Beans) } & \multicolumn{2}{l}{ Percentage of Profit } \\
& Channel 1 & Channel 2 & Channel 1 & Channel 2 \\
\hline Farmer & & & $48 \%$ & \\
Fertilizer & 9.538 & 9.538 & & \\
Pesticide & 525 & 525 & & \\
Manpower & 7.825 & 2.286 & & \\
Selling price & 34.167 & 16.000 & & \\
Profit & 16.279 & 3.651 & & \\
Processor & 34.167 & 20.000 & \\
Raw Material Purchasing & 500 & - & \\
Cherries Sorting & 4.000 & 4.000 & \\
Hulling & 2.500 & - & \\
GB Sorting & 450 & 325 & \\
Drying & - & 20.000 & \\
Roasting & 2.667 & - & \\
Depreciation of tools & 45 & 7.545 & \\
Packaging & 95.000 & 75.000 & \\
Selling price & 50.671 & 23.130 & \\
Profit & & & \\
Retail & & 75.000 & \\
Raw Material Purchasing & & 5.000 & \\
Packaging & & 100.000 & \\
Selling price & & & \\
Profit & & & \\
Roastery & & & \\
Raw Material Purchasing & 95.000 & \\
Gas & 4.929 & & \\
Electricity & 5.757 & & \\
Manpower & 26.143 & & \\
Maintenance & 4.553 & & \\
Packaging & 3.929 & & \\
Selling price & 272.857 & & \\
Profit & 130.547 & & & \\
\hline
\end{tabular}

From the estimation of the farmer share for the last 3 years the percentage of farmer shares has increased from year to year as the price of cherry coffee has been increased by the Pokmas Walida to assisted farmers. Based on the farmer share size in each year, on the first channel (Table 5) in 2017 farmers' farmer share are said to be effective because they have a figure of $\geq 40 \%$ (Downey and Erickson 1992). Meanwhile for the second channel, the farmer share received by farmers is much smaller than the first channel. On the second channel farmers only get a farmer share of $21 \%$. This shows that the second channel is not efficient.

From the size of the farmer share, an effective channel can also be seen from the percentage of profits that are evenly distributed in each component of the marketing channel. 
Value of profit is calculated from the selling price of a distribution institution minus production costs. In this researh the results of estimating profits from Argopuro coffee marketers are as follows in Table 5.

Based on the estimation of the percentage of profits, it can be seen that the percentage of farmers on the first channel is $48 \%$, processor $53 \%$, and roastery is $48 \%$. The amount of profit obtained by the processor is greater than roastery. Processor gains $53 \%$ while roastery is $48 \%$. The percentage of profits obtained by roastery is slightly smaller due to equipment investment that is far greater than the processor. Besides that, selling prices at the roastery level are very sensitive to the speed at which goods are sold, because the level of competition at the roastery level is higher than the processor.

In terms of profit, the value of each component is quite even so that the first distribution channel is efficient. But the farmer share value obtained by farmers is still not very good. The assisted farmers need further management of the sold raw materials, especially on the quality of the production of red pickled in order to increase the price of raw materials.

While on the second channel, farmers get a profit of $23 \%$, processor $31 \%$ and retail by $15 \%$. The percentage of profits on the second channel has a value that is too far and uneven so that it can be said that channel 2 isn't efficient. The size of the farmer share is also below $40 \%$, which is only $21 \%$. From the results of the estimation, farmers will benefit from selective picking rather than carelessly picking. The price of green pickled cherry is so low that the farmer share received by farmers is small. Processing institutions who determines the prices should conduct training and direct the farmers to selective picking so that farmer share of farmers can be better.

Determination of the efficiency of the marketing channel can also be accessed through a comparison of the share of profits and costs incurred by each market institution in the distribution channel. In this research the results of the calculation of the percentage of profits and costs of each marketer's institution are as follows:

Table 5 - Profit ratio and market institutions cost of Argopuro

\begin{tabular}{lllll}
\hline Chain Members & Ski & & Sbi & \\
& Channel 1 & Channel 2 & Channel 1 & Channel 2 \\
Prosessor & $83 \%$ & $39 \%$ & $73 \%$ & $88 \%$ \\
Roastery & $73 \%$ & - & $80 \%$ & - \\
Retail & & $60 \%$ & & $340 \%$ \\
\hline
\end{tabular}

Based on the calculation of the profit shares and costs obtained by marketers, the processors get a share of profits of $83 \%$ and share costs by $73 \%$. While roastery has a profit share of $73 \%$ and share costs of $80 \%$. The comparison between the profit and cost share of the two marketing institutions can be equal, so that the marketing channels that occur is efficient. A processor profit share is greater than the roastery profit share because the processors as the sole producer of Argopuro green beans specialty have greater freedom of determine the price than roastery. While the share of costs incurred by roastery is greater because of the high value of tool investment and pricing that is sensitive to the speed of sales, given the large number of roasteries located in the same area. In addition, items at the roastery level have perishable properties, Roasted beans have a 2-month expiration period, if the beans are more than two months taste and the aroma will decrease.

On channel 2, the processor has a profit share of $39 \%$ and the share of costs is $88 \%$. While retail has a share of profits of $60 \%$ and share costs of $340 \%$. Comparison between profit share and cost share of both marketer institutions is not equal and too far in value so that on channel 2 , distribution does not run efficiently.

\section{CONCLUSION AND SUGGESTIONS}

Argopuro specialty coffee distribution channel consists of farmers who play the role of red cherry suppliers, Pokmas Walida acts as a producer of greenbeans specialty grade, and roastery as Consumer B2B. 
Based on the farmer share analysis, the average yield for the last 3 years was $36 \%$, this indicates that Argopuro specialty coffee marketing channel is not yet efficient. But the value of the farmer share in 2017 has reached an efficient rate of $40 \%$.

Analysis of marketing margins and marketing margin ratio to costs shows that marketing margins at the processor level are higher than other marketing channel members. But overall the percentage of marketing margins is evenly distributed so that the distribution channel is efficient.

Pokmas Walida, which acts as a producer and market institution at the farmer level needs to pay attention to the purchase price of raw materials from assisted farmers so that the farmer share can increase and the distribution channel is more efficient.

\section{REFERENCES}

1. (ICO) Internatioal Coffee Organization. 2014. Mounthly Coffee Market report March 2014, Lodon (UK): ICO

2. (SCAA) Specialty coffee Association of America. 2016. Specialty coffee Facts \& Figures. Caliornia (US): SCAA.[30 April 2017] 14:30

3. Cristovao. 2015. Analisis Efisiensi Pemasaran dan Pilihan Saluran Pemasaran Kopi Organik di Kabupaten Ermera - Timor-Leste. [Thesis]. Bogor (ID): Institut Pertanian Bogor.

4. Downey, W. D., dan S. P. Erickson. 1992. Manajemen Agribsnis. Erlangga, Jakarta.

5. Donnet, M.Laura. (2007). Essay on specialty coffee procurement (Dissertation). Michigan (US): Michigan State University

6. Hokey et al (2010). Comparative efficiencies of specialty coffee retailers from the perspectives of socially responsible global sourcing. The International Journal of Logistics Management Vol. 21 No. 3: PP. 490-509

7. Kusuma MEW, Utami HD, Nugroho BA. Marketing Efficiency Analysis of Chicken's Egg at Karangploso Sub District Malang Regency. http://fapet.ub.ac.id/wpcontent/uploads/2013/04/Analisis-Efisiensi Pemasaran-Telur-Ayam-Ras-di-KecamatanKarangploso-Kabupaten-Malang-.pdf

8. Mayrowani H, Darwis V. 2009. Perspektif pemasaran bawang merah di Kabupaten Brebes, Jawa Tengah. Di dalam: Suradisastra K, Yusdja Y, Nurmanaf AR, editor. Prosiding Seminar Nasional Dinamika Pembangunan Pertanian dan Perdesaan: Bogor (ID): Pusat Analisis Sosial Ekonomi dan Kebijakan Pertanian. 